\title{
Minimizing Potential Issues in Higher Education by Professionally Developing University Teachers
}

\author{
Anam Siddiqui \\ MS Scholar \& Visiting Lecturer, \\ Faculty of Management Sciences, The Islamia University of Bahawalpur, Pakistan \\ E.mail: anamsiddiqui07@gmail.com
}

\begin{abstract}
Hassan Danial Aslam
Lecturer, Faculty of Management Sciences, The Islamia University of Bahawalpur, Pakistan Senior HR Research Consultant, Human Resource Management Academic Research Society E.mail: h_danial_aslam@live.com

Hafiz Muhammad Farhan

Lecturer, Faculty of Management Sciences, The Islamia University of Bahawalpur, Pakistan E.mail: farhan_rising@yahoo.com
\end{abstract}

\section{Adeel Luqman}

Lecturer, Department of Commerce, The Islamia University of Bahawalpur, Pakistan

E.mail: adeel345@yahoo.com

\section{Muhammad Arfan Lodhi}

Training Advisor, Human Resource Management Academic Research Society $\mathrm{PhD}$ Scholar \& Visiting Lecturer, The Islamia University of Bahawalpur, Pakistan E-mail: Samaritan_as@hotmail.com

Received: August 15, 2011 Accepted: October 2, 2011 Published: November 19, 2011

Doi:10.5296/ijld.v1i1.1095ＵRL: http://dx.doi.org/10.5296/ijld.v1i1.1095

\begin{abstract}
The major purposes of this paper is to firstly explore the relationship among three variables namely professional development of faculty members, teachers' performance and quality of higher education, and secondly to provide solution to perceived issues and challenges faced by higher education system with the help of comprehensive model. Authors have deeply reviewed previous research studies conducted by researchers and have elaborated their views in connection with the current debate. This paper is purely qualitative in nature and authors have formulated comprehensive model that can be helpful for the policy makers and administrators of the higher education system. This comprehensive model clearly explains that if teachers are equipped with proper and well organized pedagogical as well as administrative training
\end{abstract}


programs then their performance can be greatly improved which can further enhance the quality of education delivered to the students. Both pre-service and in-service professional development programs should be organized for faculty members that will improve their knowledge, skills and abilities, which in turn will further improve their academic, pedagogical and administrative job performance resulting the improvement of overall quality education. Moreover the relation that has been explored can be used to minimize many emerging problems, and perceived issues and challenges faced by higher education system. The model proposed by authors will be useful for policy makers who can then make better policies and can design improved procedures to enhance quality of education. Besides all this, the model is also helpful for management/administrators of higher education system to train and develop their faculty members on specified patterns to inculcate healthy learning among their students.

Key words: Professional Development of faculty members, Perceived Issues and Challenges to Higher Education, Quality, Quality of Education, Professional Development Programs, Performance of Faculty Members.

\section{Introduction}

Higher education of today is moving through new era and is facing immense challenges and novel problems that need to be adjusted spontaneously. The darker side of the picture is that the teaching, teacher education and teacher training in higher education is getting least attention (Sheikh, 2007). As Jan (2007) emphasized that there is great need to improve traditional teaching methodologies and styles, teacher-student relationship, and pedagogical skills and knowledge base of teachers. Moreover higher education of today is crossing from novel landscape and is facing exciting challenges like as increasing national and international competition, increasing number of diversified students, exceeding expectations of stakeholders, globalization, revolution in information technology and changing teaching methodology. Teachers are the main pillars of academic institutes that offer teaching services to students. Therefore proper training and development of faculty members is crucial. Various techniques can be used for teacher education and teacher training, so that their pedagogical, professional, administrative and teaching skills can be groomed through it consequently. Only few previous researches are present regarding professional development of faculty members in developing nations. This study is important for management/administrators and policy makers of higher education as well as for students because teacher education and teacher training will improve interactive and pedagogical skills of teachers to enhance quality of education delivered to students. The management can be benefited in terms of attracting and retaining competent faculty members and to improve quality of education delivered at their institutes. If management and faculty members jointly plan for effective professional development programs then quality of education can be improved as students' learning exposure will increase, and institute will be able to meet national and international quality standards of education. The primary beneficiaries of professional development activities will be teachers and secondary will be students. Through such act emerging problems, issues and challenges 
faced by higher education system can be resolved and overall effectiveness of the institute can be increased.

\section{Professional Development of Faculty Members}

According to Mirza (2007) various terminologies have been used to describe development of faculty members as In-Service Training, Staff Development, Faculty Development, and Professional Development. Various authors have defined professional development in different ways as according to Eble \& McKeachie (1985) faculty development has both broader and narrower focus as in broader term it focuses mainly on student learning, whereas in narrower term it focuses on improving and maintaining professional competencies of teachers. In the same way Moeini (2003) has defined faculty development as the process of encouraging academic scholarship of individual faculty members. It includes various programs and strategies that are meant to improve competencies and maintaining their knowledge for better job performance at the institute. Similarly Memon (2007) has also defined that professional development is a vibrant and continuous process that is used to improve and to increase knowledge, pedagogy, and experience of teachers.

As various researchers have elaborated the term "Professional Development" differently therefore Professional Development of faculty members in authors' viewpoint are those activities that are aimed to improve and enhance academic and professional knowledge, skills, abilities and capabilities of teachers. Professional Development activities are meant to help teachers to revitalize their existing teaching and learning experiences, and motivate them to tackle emerging internal and external challenges.

\subsection{Professional Development Programmes}

There are various professional development activities and programs that are used in academic institutes across developed and developing nations to professionally groom their teachers. As Mirza (2007) explained that there are varieties of professional development activities, which include short courses, extended, or long courses that may take place once a week on Sundays mostly or may cover longer time span of about two years, and those courses that lead to award certificates and degrees to the participants. Some academic institutes also offer various incentives on achieving formal courses as promotions, earning of certificates and degrees, and recognition (Mirza, 2007). In the same way Hoban (2002) described that there are two types of learning that take place through professional development activities as, "Transformative Learning" i.e. renewing teaching practices and old teaching methods and "Generative Learning" i.e. creating new knowledge. This means that professional development activities not only help in obtaining new knowledge but also help in renewing the existing knowledge and information base of teachers. Such professional development strategies can widen thinking capabilities and creativity of teachers and such teachers would teach their students in better way. 
Similarly Sajjad (2007) has elaborated that faculty development programmes include six modules as improving educational psychology, advancing teaching, administrative and communication skills, helping teachers in curriculum development, upgrading research skills and expertise, and measuring and evaluating teachers' performance. All these modules address cognitive and professional skills of faculty members.

Memon (2007) has also discussed few traditional professional development approaches that were used previously to develop faculty members as;

1. Orientation,

2. Induction,

3. Apprenticeship,

4. Auditing,

5. Team teaching and

6. Pedagogical skill development programme for new teachers.

Moreover Memon (2007) has also described few contemporary approaches that are more effective on continuous basis as;

1. Mentoring,

2. Appraisal by self and others,

3. Action research,

4. Self reflection/ evaluation,

5. Peer coaching / peer reviews,

6. Clinical supervision/peer consultancy,

7. Group work / team learning professional consultancy,

8. Observing good practices,

9. Participation in conferences/ seminar workshops,

10. Students' feedback,

11. Participation in academic / curriculum development / reviews,

12. Organizational development / reviews,

13. On-line / distance education programme,

14. Research and scholarship activities,

15. Re-conceptualization of scholarship activities.

However Ali (2007) elaborated that there are two approaches that are used to develop teachers as;

- Pre-Service Education,

- In-Service Education.

Pre-service education means that when teachers are getting professional education, the faculty members must transfer right concepts, updated knowledge and information and let their students practically implement knowledge so that they can understand the relevance of 
knowledge in market. The student of today is teacher of tomorrow, so if concrete foundations will not be laid down today then how strong architecture can be built for tomorrow. Other than bookish knowledge, teachers must try to share their personal experiences with students that will definitely help them think intuitively and deliver market relevant information to them. Academic institutes must polish their students' abilities, skills and knowledge by not just effectively designing the courses and teaching techniques but also work to develop students personally, professionally and academically. Various seminars, workshops, and internship programs must also be organized for students that can act as first step towards their professional development (Ali, 2007).

On the other hand in-service education can be acquired through books, journals, research papers and secondary material that teachers used to update their knowledge. The role of supervisor is also very critical for developing and training teachers effectively (Ali, 2007). If mentors are supportive, and good learning environment is present to learn and transfer training material then training objectives can be achieved successfully. Supervisors must provide development opportunities to their subordinates equally and fairly. These activities include lectures, seminars, workshops, conferences, local association meetings and occupational experiences (Boser and Daugherty, 1994). Similarly Glazener (1968) has identified that the in-service education activities include workshops, conferences and seminars.

\section{Performance of Faculty Members}

Performance of employees greatly impacts the outcomes of an organization. It is believed that if employees are performing well then intended goals could be achieved. Performance of faculty members can be measured through several indicators. As according to Ory (1991) teachers' performance can be measured through students rating, peers rating and course portfolio. Similarly according to Braskamp and Ory (1994) faculty members invest a lot of time in activities in addition to teaching students as performing administrative functions, public services to communities, advising and providing mentoring to students and subordinates, and attending training course that might include workshops, conferences and seminars etc.

In the same way Hassna and Raza (2000) explain in their paper that teachers' performance can be evaluated on the basis of three indicators as teaching performance, scholarly endeavor and other services. Teaching performance can be measured in terms of students rating and course content being delivered to students. Scholarly endeavor includes the research work and publications done by teachers while other services include advising and coaching students and participating in training courses. Similarly Harrison (2002) has explained that major service of university is to teach students and conduct research so that teachers' performance can be measured in terms of research work that they conduct and teaching services. However Kara and DeShields (2004) have described that teaching performance of faculty members could be measured in terms of students' understanding of subject matter that is taught by teachers, availability and accessibility of teachers, professionalism of faculty members and timely 
feedback. This shows that performance of faculty members could be measured by investigating teaching, research and administrative activities of the teachers in universities.

\section{Quality of Education}

The term Quality is being used widely now a days and is attached to various day to day elements. As Vroeijenstijn (1995) described that the concept of quality is not new however it has traditional orientation. Similarly McConville (1999) described that there is no exact definition of "quality", one will know it only when one will find it. Similarly Pfeffer and Coote (1991) had referred it as a "Slippery Concept". Various researchers had defined this term differently as British Standard Institution (BSI) defined quality as "the totality of features and characteristics of a product or service that bears on its ability to satisfy stated or implied needs" (BSI, 1991). Various researchers have defined quality of education differently as Chapman and Adams (2002) described that quality education comprises of four elements as Input; (as number of teachers in institute, amount of teacher training, number of books, course and curriculum), Process; (as teaching and learning time, and extent of active learning), Output; (as test scores and number of graduates passing out in a period) and Outcomes; (as performance in subsequent employment).

Similarly Westerheidjen (1999) have described that it is difficult to define quality in higher education because there is lack of theoretical background on quality of higher education. Raouf (2008) has thrown light on importance of continuous improvement of higher education quality. Researcher emphasized on regular evaluation of system's input, process and output. However Adams (1998) has given a comprehensive view of quality as the extent to which institute can influence students' knowledge, attitudes, values, and behaviors or more comprehensively how knowledge has been acquired and effectively applied. Similarly Al-Azzah and Yahya (2010) refer that major goal of quality is to acquire "Customer Satisfaction". In case of universities their customers are students so according to this definition it means that management must try to achieve students' satisfaction.

Similarly according to Pervaiz, Shahin, Muzaffar, and Azad (2007) quality of education and research done by universities is largely determined by the quality of faculty members and the services that they offer. In the same way Khawaja (2007) described that quality of higher education can be improved by adopting modernized and computerized system of teaching. This view supports that new and modernized techniques and methods of teaching should be used to teach the students. High quality of education means that the students should get better social skills, diverse employment opportunities and personal fulfillment. Quality of education has many dimensions such as quality of students admitted in university, resources and facilities provided as libraries, labs etc, fair and equitable environment and justice for every one, meeting quality standards, and quality and quantity of teachers. However the most important dimension according to Pervaiz, et. al (2007) is the quality of teachers. For any university to offer satisfied teaching and research services, it is highly crucial that it must possess highly qualified and competent staff. 
In the same way according to Bennett (2001) quality in higher education can be assessed by observing students development. Value added is the measure of observing the difference between level of development of students before and after getting education from university. Moreover Bennett (2001) further added that if outcomes are assessed properly revealing what students have achieved in terms of capabilities, skills, and knowledge, then one can measure quality of higher education. In addition, the ranking of university can also show that how much effectively it is in offering better and good quality of education. Quality can also be assessed by looking up the resource input of the institute as how much finance is allocated per student, and the human resources that include mainly number of qualified faculty members that institute possesses. Moreover students' rating is also the best and valid measure to assess quality of higher education system (Bennett, 2001).

Similarly Chapman and Adams (2002) described following characteristic of quality in academic institute. As;

- Effective teaching methodologies and techniques designed to encourage independent and innovative thinking;

- Capable, motivated, well-trained faculty members;

- Appropriate, well-designed and relevant curriculum;

- Effective learning materials including, but not limited to, textbooks;

- Well-maintained learning environment;

- A valid, reliable examination system;

- Strong influential leadership;

- Sufficient direct instructional time;

- Adequate financing; and

- Effective organizational structure and support.

\section{Perceived Issues and Challenges to Higher Education}

Hoodbhoy (1998) explained that higher education system of developing and underdeveloped nations are working unsatisfactorily. Higher education of today is crossing from novel landscape and is facing exciting challenges as increasing national and international competition, increasing number of diversified students, hiking expectations of stakeholders, globalization, revolution in information technology and changing teaching methodology (repetition page 2). Various problems in Teaching-Learning process in higher education institutes have been identified by several researchers as Siddique (2006) described that learning is mostly book oriented. Students rely on memorizing content that was provided to them in classes. Similarly Hoodbhoy (1998); Khawaja (1994); Ahmed (1992); and Ali (2005) explained that teaching methods used in higher education institutes are traditional and ineffective in imparting learning in students.

In the same way Ali (2007) reveals that situation of professional development of faculty members is highly disappointing. Participants don't have required basic skills and knowledge 
to acquire training. Old teaching methodologies are in place that is because of lack of management, commitment and inadequate planning. Participants are less motivated to acquire training and do not know the importance of training.

\section{Discussion}

After conducting an extensive and in-depth literature review, authors have come up with a comprehensive model. This model firstly explains the relationship among three variables as professional development of faculty members, performance of faculty members and quality of higher education, and secondly it explains that this relationship could be used as a solution for many above stated perceived problems and emerging issues and challenges to higher education system.

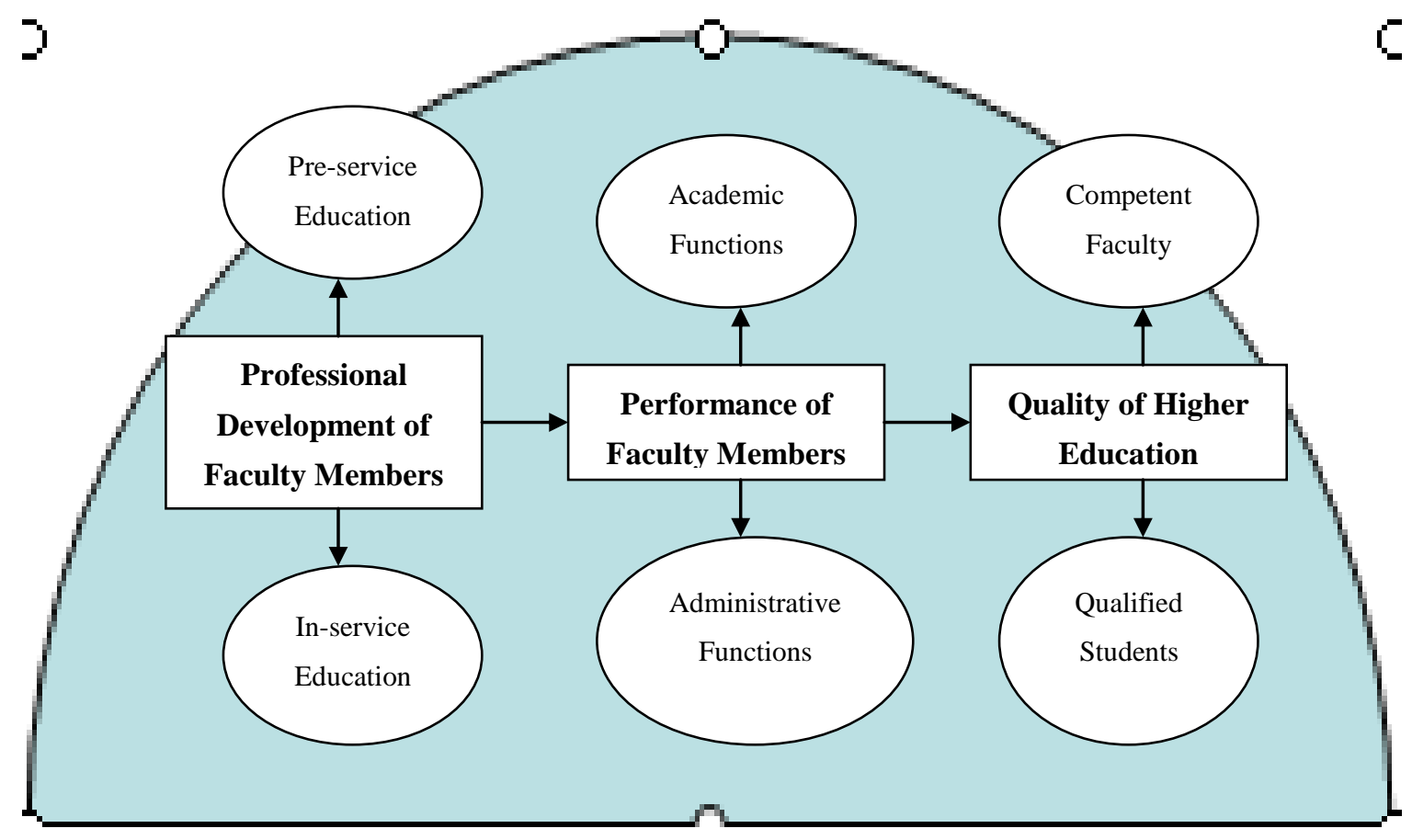

\section{Mushroom Model of Higher Education System}

Authors have named this model as Mushroom Model as the shape of this model is much similar to mushroom. The model explains that if proper training is provided to faculty members then their performance will be improved positively and that will further improve overall quality of education provided to students. Pre-service and in-service training is essential for developing existing and novel competencies of teachers. The responsibility is two fold where not only supervisors should arrange training for their staff, but teachers' self urge and interest to acquire training is also critical. Teachers must also try to continuously groom their professional expertise and teaching skills before and after getting job in universities. Prior 
learning will act as a building block for further enhancement and improvement of knowledge and information. Administrators must try to organize various short and long term training programs (workshops, seminars, conferences, research work and publication, performance assessment and timely feedback) for teachers to upgrade teachers' professional skills and competency.

Effective professional development of teachers will not only improve their academic performance but also put positive effects on their administrative performance. Academic performance includes teaching and research functions provided by faculty members and administrative performance includes functions as helping, supporting and guiding students, attending and delivering training, participating in various formal and informal inter-university and intra- university activities. Through training and professional enhancement workshops based upon this model, teachers' knowledge and pedagogical skills will be polished, developed, organized and enhanced. They will be able to teach their students in more effective manner. Moreover they will be able to perform other services in professional manner.

When teachers will be well trained and competent, and will perform their job in effective manner then overall quality of education delivered to students will improve. Competent and skilled staff will impart learning in students and will develop them personally and professionally. Those students will not be just crammers of textbooks but their knowledge base will comprise of both implicit and explicit knowledge. Such students will surely be able to get good jobs in the markets after completing education.

It has now become evident that effective and well planned professional development could improve teachers' performance that can further enhance quality of education and through this many potential problems and emerging issues and challenges faced by higher education system can be catered well. The problems like globalization, hiking national and international standard of education, advancement in IT, primitive and ineffective methods of teaching, hiring less qualified and competent teaching staff and retaining highly competent academic staff can be addressed well by properly conducting trainings for faculty members.

\section{Conclusion and Future Implications}

The Model of Higher Education System described above explains that if proper professional development activities are carried out in universities then performance of teachers can be improved that will further enhance quality of education provided to students in universities. Moreover training of faculty members can also minimize many potential problems and emerging issues to higher education that need to be addressed quickly. This model is useful for the management and policy makers of the universities who can devise better policies and procedures to accommodate emerging problems and to improve quality of education delivered. The model is consistent with the studies of Ali (2007); Braskamp and Ory (1994), Hassna and Raza (n.d.), Pervaiz, et. al (2007) and Bennett (2001). 


\section{Macrothink

As far as limitations of this study are concerned, various contextual factors must be explored to improve the model and further in-depth study is required for the variables under question. The model is general and can only be applicable after considering all specifications. Researchers can further refine this model and can view its applicability by empirically testing it in future. 


\section{References}

Adams, D. 1998. Defining Educational Quality: Educational Planning. Educational Planning 11(2):3-18.

Ahmed, M. (1992). "Pakistan" in W. Wickermasinghe (Ed) Handbook of World Education: A Computer Guide to Higher Education and Educational Systems of The World. Housten, Texas: American Collegiate Service.

Al-Azzah, F. M., and Yahya, A. A. (2010). "Quality Procedures to Review, Mission, Vision and Objectives in Higher Educational Institutions". European Journal of Scientific Research, ISSN 1450-216X Vol.45 No.2, pp.168-175.

Ali, A. (2005). A study of academic functioning of universities in Pakistan: An unpublished thesis.

Ali, T. (2007). "Professional development of teachers at higher education in Pakistan enhancing the quality of higher education professional development content and strategies)". Paper presented at National Conference on Professional Development of Teachers in Higher Education in Pakistan: Organized by National Academy of Higher Education (NAHE).

Bennett, D. C. (2001). “Assessing Quality in Higher Education”. Volume 87, No. 2. Retrieved on March 2011, from http://www.aacu-edu.org.

Boser, R. A. \& Daugherty, M. K. (1994). In-Service Activities for Technology Education: The Role of Colleges and Universities. Journal of Technology Education. Volume 6, Number 1

Braskamp, L. A. and J.C. Ory. (1994). “Assessing faculty work”. San Francisco: Jose Bass, $333 \mathrm{p}$

BSI (1991). “Quality Vocabulary Part 2: Quality Concepts and Related Definitions”. London: BSI.

Chapman, D. and Adams, D. (2002): "The Quality of Education: Dimensions and Strategies" .Published By Asian Development Bank Comparative Education Research Centre the University of Hong Kong. Vol. 5.

Eble, K. E. \& McKeachie, W. J. (1985). "Improving undergraduate education through faculty development: An analysis of effective programs and practices". San Francisco: Jossey-Bass.

Glazener, E. W. (1968). In-Service Education for Teaching Faculty. Journal of Animal Science. Retrieved on August 28, 2011, from http://jas.fass.org/content/27/Symposium/925.full.pdf 
Harrison, J. E. (2002). The Quality of University Teaching: Faculty Performance and Accountability. A Literature Review. CSSHE Professional File.

Hassna, L. O. and Raza, S. (2000). An assessment of the relationship between the faculty performance in teaching, scholarly endeavor, and service at Qatar University. An assessment of the relationship. Research in Higher Education Journal.

Hoban, G. (2002). Teacher Learning for Education Change, Buckingham, Open University Press.

Hoodbhoy, P. (1998). "Pakistani Universities: Which Way Out?" In Hoodbhoy (ed): Education and the state: Fifty years of Pakistan. Karachi OUP

Jan, A. A. (2007). “Mentoring as a Tool of Teacher Development”. Paper presented at National Conference on Professional Development of Teachers in Higher Education in Pakistan: Organized by National Academy of Higher Education (NAHE).

Kara, A. and DeShields, O. W. (2004). Business Student Satisfaction, Intentions and Retention in Higher Education: An Empirical Investigation. MEQ Vol 3

Khawaja, M.G. (1994). Pakistan Education System: A Research Work On Research Methodology Lahore: College Of Business Administration

Khawaja, W. (2007). "Collaboration of HEC with Higher Education Institution". Abstracts of the posters presented in the conference; Empowering Academic Leaders; Proceedings: National Conference on Professional Development of Teachers in Higher Education in Pakistan.

McConville, G. (1999). "Everybody Wants Quality Education: But What Does It Mean?" Australian Universities Review, 42(2), pp. 2-4.

Memon, M.A. (2007). "Professional Development of Teachers in Higher Education Institutions in Pakistan: Some Alternatives". Paper presented in; Proceedings: National Conference on Professional Development of Teachers in Higher Education in Pakistan.

Mirza, M. S. (2007). "Professional Development of Teacher in Higher Education in Pakistan". Keynote Address; Empowering Academic Leaders- Proceedings National Conference on Professional Development of Teachers in Higher Education in Pakistan.

Moeini, H. (2003). "A Need Analysis Study for Faculty Development Programs In Metu And Structural Equation Modeling Of Faculty Needs". In Partial Fulfillment of The Requirements 


\section{Al Macrothink}

International Journal of Learning \& Development

ISSN 2164-4063

2011, Vol. 1, No. 1

For The Degree Of Doctor Of Philosophy In The Department Of Computer And Instructional Technologies Education.

Ory, J. C. (1991). "Changes in evaluating teaching in higher education". Theory into Practice, Vol.30, pp. 30-36

Pervaiz M. K., Shahin F., Muzaffar H., \& Azad M. (2007). "Strengths and Weakness of Teachers Involved In Higher Education (A Case Study)". Empowering Academic LeadersProceedings National Conference on Professional Development of Teachers in Higher Education in Pakistan

Pfeffer, N. \& Coote, A. (1991). Is Quality Good For You? A Critical Review of Quality Assurance in Welfare Service, London: Institute Of Public Policy Research.

Raouf, A. (2008). "Continuous Improvement of Higher Education Quality". Paper Presented At 2nd International Conference On Assessing Quality In Higher Education, Lahore Pakistan.

Sajjad S. (2007). "Staff Development Programme at Higher Education Level in Pakistan Issues and Challenges". Paper Presented in- Proceedings National Conference on Professional Development of Teachers in Higher Education in Pakistan.

Sheikh, S. H. (2007). "Evaluation Of The Teachers By The High Ups, By The Students, By The Peers And Self Assessment: Study Of Three Dimensional System Of Teachers' Evaluation In The Universities Of Pakistan". Paper Presented in- Proceedings National Conference on Professional Development of Teachers in Higher Education in Pakistan

Siddique, Z.S. (2006). "Study approaches of students in Pakistan: the revised two factor study process questionnaire experience". Occasional Report. Islamabad: (NAHE,HEC)

Vroeijenstijn, A.I. (1995). "Improvement and Accountability, Navigating Between Scylla and Charybdis, Guide for Quality Assessment in Higher Education”. (London, Jessica Kingsley Publishers).

Westerheijden, D.F. (1999). "Where Are The Quantum Jumps In Quality Assurance? Development of a Decade of Research on a Heavy Particle". Higher Education, 38(2), pp. 233-254. 